\title{
PROGESTERONE CONCENTRATION, PREGNANCY AND CALVING RATE IN SIMMENTAL DAIRY COWS AFTER OESTRUS SYNCHRONISATION AND hCG TREATMENT DURING THE EARLY LUTEAL PHASE
}

\author{
Adam Šuluburić ${ }^{1}$, Svetlana Milanović ${ }^{2}$, Sanja VRANJeŠ-Đurić ${ }^{3}$, Ivan B. Jovanović2 \\ Tomislav BARNA ${ }^{4}$, Milica STOJIĆ ${ }^{2}$, Natalija FrATRIĆ ${ }^{2}$, Ottó SzENCI ${ }^{5,6}$ and Dragan GVOZDIĆ ${ }^{7 *}$ \\ ${ }^{1}$ Veterinary Ambulance Dragačevo-Vet, Guča, Serbia; ${ }^{2}$ Department of Physiology and \\ Biochemistry, Faculty of Veterinary Medicine, University of Belgrade, Belgrade, Serbia; \\ ${ }^{3}$ Vinča Institute of Nuclear Sciences, University of Belgrade, Serbia; ${ }^{4}$ Department of \\ Reproduction, Scientific Veterinary Institute Novi Sad, Novi Sad, Serbia; ${ }^{5}$ Department \\ and Clinic for Production Animals, University of Veterinary Science, Üllö, Dóra major, \\ Hungary; ${ }^{6}$ MTA-SZIE Large Animal Clinical Research Group, Üllö, Dóra major, \\ Hungary; ${ }^{7}$ Department of Pathophysiology, Faculty of Veterinary Medicine, \\ University of Belgrade, Bulevar Oslobođenja 18, 11000 Belgrade, Serbia
}

(Received 2 December 2016; accepted 4 April 2017)

Early embryonic development may be negatively affected by insufficient progesterone (P4) production. Therefore, the aim of our study was to increase P4 by gonadotropin-releasing hormone $(\mathrm{GnRH})$ and/or human chorionic gonadotropin (hCG) treatments after inducing oestrus by prostaglandin (PG) treatment. Lactating Simmental dairy cows $(n=110)$, between 1 to 5 lactations, with an average milk production of 6,500 1/305 days, at 40-80 days postpartum were used and grouped as follows: (1) PG $+\mathrm{GnRH}$ treatment at $\mathrm{AI}$ (GnRH group), (2) $\mathrm{PG}+$ hCG treatment at day 7 after AI (hCG group), (3) PG + GnRH at AI + hCG treatment at day 7 after $\mathrm{AI}(\mathrm{GnRH} / \mathrm{hCG}$ group), and (4) spontaneous oestrus (C: control group). All animals were double inseminated (at the time of oestrus detection and $12 \pm 2 \mathrm{~h}$ thereafter). Blood serum and milk samples were collected at the day of observed oestrus (day 0), and 14, 21 and 28 days after AI. Serum P4 was determined using a commercial radioimmunoassay (RIA) test (INEP, Zemun), and milk P4 was determined using enzyme-linked immunoassay (ELISA) test (NIV Novi Sad). Pregnancy status was confirmed by ultrasonography between days 28 and 35 after AI. Differences of serum or milk P4 medians, pregnancy (and calving) rate were determined using Dunn's Multiple Comparison Tests and $\mathrm{Z}$ test, respectively. Serum P4 medians were significantly higher at days 14, 21 and 28 after $\mathrm{AI}$ in the hCG-treated animals, indicating increased luteal activity, with a similar tendency in whole milk P4 values. Treatment with hCG during the early luteal phase significantly contributed to the maintenance of gestation at days 28-35 after AI, and also increased the calving rate in Simmental dairy cows.

\footnotetext{
*Corresponding author; E-mail: gvozdic@vet.bg.ac.rs; Phone: 00381 (63) 779-9923
} 
Key words: Progesterone, oestrus synchronisation, pregnancy rate, calving rate, Simmental dairy cows

Reproduction efficiency of dairy cows has declined worldwide and pregnancy rates after artificial insemination (AI) are usually between 30 and $40 \%$ (Royal et al., 2000; Gvozdić et al., 2011). Since the first report by Pursley et al. (1995) about the Ovsynch protocol, many oestrus synchronisation programmes have been developed and tested. Almost all types of synchronisation protocols are based on the orderly usage of prostaglandin F2alpha $\left(\mathrm{PGF}_{2 \alpha}\right)$ and gonadotropin releasing hormone (GnRH) (Macmillan, 2010).

Utilizing oestrus synchronisation programmes in dairy cow reproduction management has two major goals: (1) bypassing the human activity and errors in oestrus detection; (2) an achievement of a pregnancy rate (PR) at least comparable to the level observed after spontaneous oestrus detection and AI. However, it seems that the average PR in the most synchronisation programmes rarely exceeds $40 \%$, and not many of them have succeeded to reduce the incidence of early embryonic mortality rate (Macmillan, 2010). Pregnancy failure could be the result of insufficient luteal progesterone (P4) production during the early stages of embryonic development (Shelton et al., 1990; Mann and Lamming, 1999, 2001).

Meta-analysis of 17 progesterone supplementation studies indicated that treatments during the first week after AI could result in increasing pregnancy rates (Mann and Lamming, 1999). Mann et al. (2006) indicated that early progesterone supplementation resulted in a fourfold increase in trophoblastic length and a sixfold increase in the uterine concentration of interferon- $\tau$ (IFN- $\tau$ ). Human chorionic gonadotropin (hCG) has an activity similar to luteinising hormone (LH) and, after binding to LH receptors, increases P4 secretion from small luteal cells (Stevenson et al., 2007). Administration of human chorionic gonadotropin (hCG) on day 5 after oestrus could result in the formation of accessory CL and hypertrophy of the original CL, which is accompanied by an increase of $\mathrm{P} 4$ concentration from day 7 onwards (Rizos et al., 2012). This increase of P4 concentration is positively correlated with the conceptus area that is highly correlated with the secretion of IFN- $\tau$ in vitro (Rizos et al., 2012; Maillo et al., 2014). Treatment with hCG several days after AI could induce ovulation of the firstwave dominant follicle(s) leading to the formation of additional luteal tissue and an increase in plasma P4 concentration and PR in dairy cows (Rajamahendran and Sianangama, 1992; Sianangama and Rajamahendran, 1992; De Rensis et al., 2010; Khoramian et al., 2011). Nascimento et al. (2013) reported that the use of CIDR + hCG could elevate P4 concentration in lactating cows and heifers. An alternative treatment could be gonadotrophic releasing hormone $(\mathrm{GnRH})$ application, but the rise in progesterone concentration is more pronounced after using hCG (Schmitt et al., 1996b). 
Our previous study indicated that in repeat breeding dairy cows hCG treatment could be a valuable tool for increasing reproduction efficiency (Gvozdić et al., 2013), presumably based on the increasing circulating P4 level during the period of early embryonic development. Walton et al. (1990) also reported that the administration of hCG (1500 IU) on day 5 after oestrus resulted in a sustained increase of milk P4 concentration in repeat breeding dairy cows, with a pregnancy rate of $47.2 \%$ compared to $39.5 \%$ in saline-treated controls.

Our working hypothesis was to use GnRH (at oestrus detection) and/or hCG (at day 7 after oestrus detection and AI) in a simple protocol of oestrus synchronisation using $\mathrm{PGF}_{2 \alpha}$ treatment of eligible Simmental dairy cows between 40-80 days postpartum, and to determine possible differences in serum P4 and milk P4 levels during early pregnancy, aiming for an increased pregnancy rate.

\section{Materials and methods}

Experimental animals, blood serum and milk sampling

The study was conducted in a dairy herd consisting of 1500 animals at the farm 'Lazar' in Blace, Republic of Serbia. A total of 110 healthy Simmental dairy cows, between 1-5 lactations, with an average milk production of 6400 1/305 days in milk, between 40-80 days after parturition, were included in the experiment. The available reproductive efficiency parameters of the experimental animals are presented in Table 1 .

\section{Table 1}

Parameters of reproductive efficiency in experimental animals (mean $\pm \mathrm{SD}$ )

\begin{tabular}{lc}
\hline Lactation no. & $3 \pm 2$ \\
First conception age (months) & $17 \pm 1.5$ \\
First calving age (months) & $26 \pm 1.5$ \\
Calving interval (days) & $420 \pm 90$ \\
First postpartum oestrus (days) & $34 \pm 8$ \\
First insemination after calving (days) & $62 \pm 16$ \\
Number of inseminations/conception (previous lactation) & $2 \pm 3$ \\
Inter-oestrus period (days) (previous lactation) & $21 \pm 1$ \\
Days open (DO) (previous lactation) & $133 \pm 74$ \\
\hline
\end{tabular}

The nutrient content of the daily ration of Simmental dairy cows used in the experiment is presented in Table 2.

All experimental animals included in this study were clinically healthy, without evidence of puerperal diseases. Experimental animals were considered eligible for oestrus synchronisation when diagnosed with a CL after rectal palpation, and were treated with $\mathrm{PGF}_{2 \alpha}$ (Estrumate ${ }^{\circledR}$, Vet Pharma Friesoythe GmbH, Friesoythe, Germany) for oestrus synchronisation (except the control group of 
animals that was left untreated and subsequently observed for the signs of spontaneous oestrus). Animals treated with $\mathrm{PGF}_{2 \alpha}$ showing signs of oestrus $2-5$ days after treatment were subsequently randomly assigned to one of the following treatment groups: (1) GnRH treatment (Receptal ${ }^{\mathbb{R}}$, Intervet International $\mathrm{GmbH}$, Unterschleissheim, Germany) at the first AI; (2) hCG treatment (Pregnyl ${ }^{\circledR}$, Organon, Oss, The Netherlands) at day 7 after AI; (3) GnRH treatment at first AI, followed by hCG treatment at day 7 after AI. In order to avoid mistakes that can be introduced by late ovulation or false oestrus, all cows had been checked and confirmed by rectal palpation. Findings identified by rectal palpation on the uterus and ovaries were recorded. Rectal palpations and artificial inseminations (AI) were conducted by experienced veterinarians and only cows with mature follicles were inseminated. Twelve hours $( \pm 2 \mathrm{~h})$ after the first AI the cows were subjected to the second rectal palpation and AI. All experimental animals were checked for pregnancy at days 28-35 after AI by means of ultrasonography (Easi-Scan ${ }^{\mathrm{TM}}$, BCF technology, Bellshill, UK). Cows were considered pregnant when an irregularshaped, non-echogenic black spot or spots were recognised within the uterine lumen, representing the allantoic fluid, and a CL on the ipsilateral ovary was detected. The experimental protocol with the number of animals and treatments is presented in Table 3.

Table 2

Nutrient content of the daily ration for experimental Simmental dairy cows

\begin{tabular}{lr}
\hline Dry matter (DM), kg & 23.05 \\
Net energy of lactation (NEL), MJ & 169.89 \\
Crude protein (CP), \% DM & 16.89 \\
Rumen undegradable protein (RUP), \% CP & 35.69 \\
Fat, \% DM & 6.69 \\
Fibre, \% DM & 22.99 \\
Acid detergent fibre (ADF), \% DM & 31.06 \\
Neutral detergent fibre (NDF), \% DM & 50.08 \\
\hline
\end{tabular}

\section{Blood serum and milk sampling}

Blood serum and milk samples were collected on the day of observed oestrus (day 0 ) and then 14, 21 and 28 days after AI. Blood for serum P4 samples was collected from the coccygeal vein using BD Vacutainer ${ }^{\circledR}$ serum tubes (Demophorius, Cambridge, UK). Serum was separated after spontaneous coagulation at room temperature and stored at $-18{ }^{\circ} \mathrm{C}$ until analysed. Approximately $8 \mathrm{~mL}$ of milk from clinically healthy quarters was sampled at the beginning of morning milking in plastic tubes $(10 \mathrm{~mL}$, Spectar, Čačak, Serbia). Potassium dichromate tablets of $3.3 \mathrm{mg}$ (Merck, Darmstadt, Germany) were used as a preservative during transportation and storage of milk samples. Milk samples were stored in a refrigerator at $+4{ }^{\circ} \mathrm{C}$ until analysed. 
Table 3

Experimental animals and treatment protocols $(\mathrm{n}=$ number of experimental animals $)$

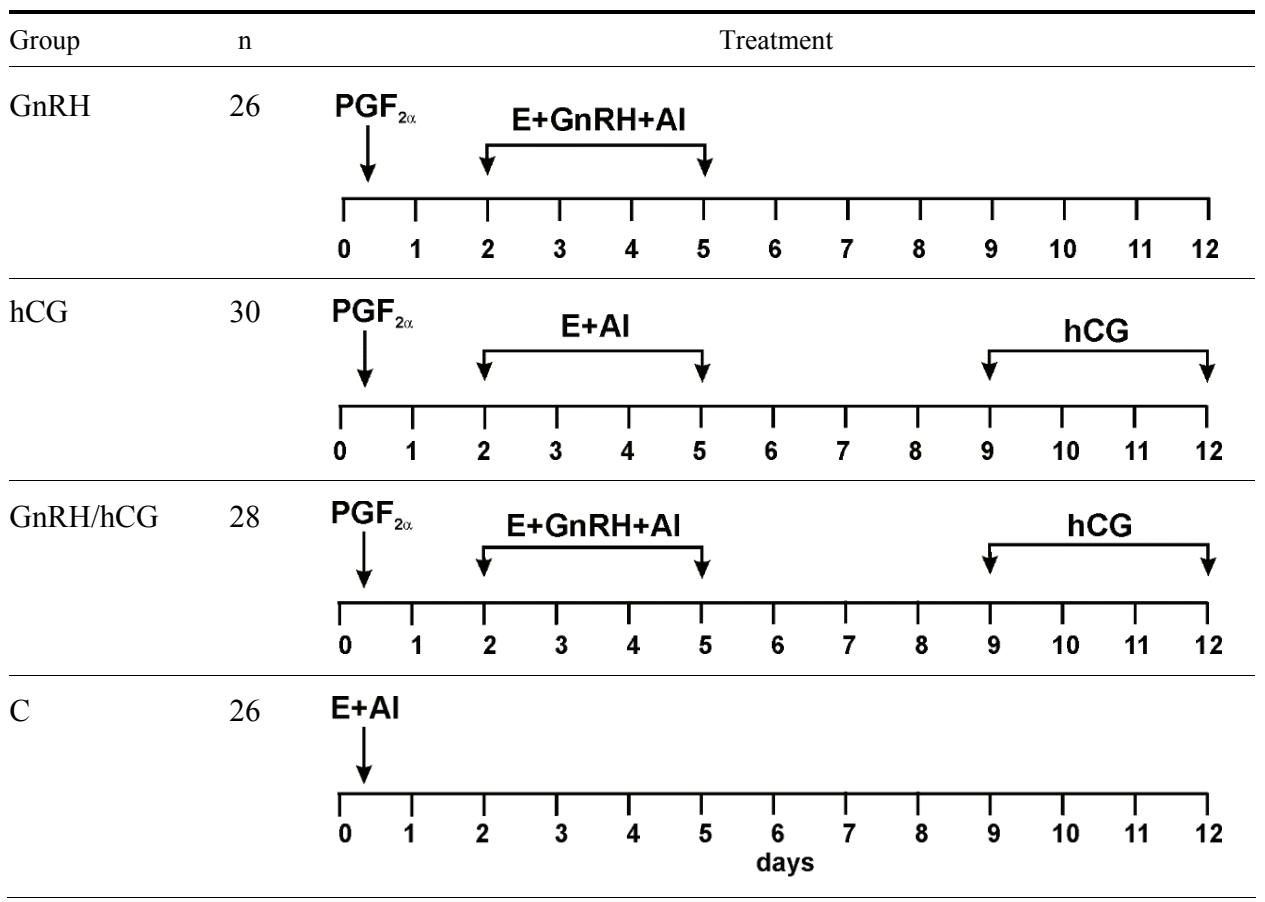

$\mathrm{C}$ - control, spontaneous oestrus; $\mathrm{PGF}_{2 \alpha}-0.25 \mathrm{mg} / \mathrm{mL}, 2 \mathrm{~mL} / \mathrm{animal}$, i.m.; E - oestrus detection; $\mathrm{AI}$ - double AI (first AI at the time of oestrus detection and second AI $12 \pm 2 \mathrm{~h}$ later); GnRH $0.05 \mathrm{mg} / \mathrm{mL}, 2 \mathrm{ml} / \mathrm{animal}$, i.m. at the time of oestrus detection; $\mathrm{hCG}-1500 \mathrm{IU} / \mathrm{animal}$, i.m., 7 days after the second $\mathrm{AI}$

\section{Blood serum and milk progesterone analyses}

Blood serum P4 concentration was determined using commercial radioimmunoassay test (RIA Progesterone PEG test, Institute for Application of Nuclear Energy - INEP, Zemun, Serbia). Maximal values for inter- and intraassay coefficients of variation were $9.37 \%$ and $7.52 \%$, respectively. The level of P4 in whole milk samples using enzyme immunoassay (ELISA) progesterone test was determined in the Scientific Veterinary Institute 'Novi Sad', Novi Sad, Serbia. Anti-progesterone antibodies, protocol for assay and protocol of production of HRP-P4 were obtained from the Laboratory of Theriogenology, Department of Veterinary Medicine, Faculty of Agriculture, Yamaguchi University, Japan. Substrates for the ELISA test were produced by INEP. Optical density (extinction) was recorded using a plate reader (Rayto Life and Analytical Science Co. Ltd., Shenzhen, China) with a filter wavelength of $450 \mathrm{~nm}$. Maximal values for interand intraassay coefficients of variation were $8.5 \%$ and $8.6 \%$, respectively. 


\section{Statistical analysis}

The differences in median P4 concentration values between experimental groups and subgroups were determined using analysis of variance (ANOVA), Kruskal-Wallis and Dunn's Multiple Comparison Tests $(\mathrm{P}<0.05$ was considered statistically significant).

The differences between proportions of the pregnant animals (PR, pregnancy rate, $\%$ of pregnant animals at days $28-35$ post-AI) and calving rate (CR, $\%$ of calved animals) in the experimental groups were tested using $\mathrm{Z}$ test of statistical significance at $\mathrm{P}<0.05$ level of significance (http://www.socscistatistics. com/tests/ztest/).

\section{Results}

Blood serum and whole milk $\mathrm{P} 4$ concentrations in the experimental groups after AI are presented in Fig. 1.

The treatment of experimental animals with $\mathrm{hCG}$ induced a significant increase in blood serum P4 concentrations at days 14, 21 and 28 (Fig. 1A, B, C), while milk P4 values remained relatively stable at day 14 in all experimental groups (Fig. 1D). However, there was a tendency for increased milk P4 concentrations in hCG-treated animals, as indicated by the significantly higher $(\mathrm{P}<$ 0.05 ) whole milk $\mathrm{P} 4$ concentrations at days 21 and 28 in the hCG-treated group of dairy cows compared to the control (Fig. 1E, F).

The results of pregnancy rate (PR, \% of pregnant animals) and calving rate (CR, \% of calved animals) in the control group and in all experimental groups, including their subgrouping in the total number of treated animals, and the statistical significance of differences between them are presented in Table 4.

There was a significantly increased PR in all treated groups compared to the control group of animals $(54 \%, 62 \%, 63 \%$ vs. $31 \%, \mathrm{P}<0.05$, in the $\mathrm{GnRH}$, $\mathrm{GnRH} / \mathrm{hCG}$, hCG vs. the C group, respectively). Furthermore, by summarising the number of pregnant animals in all treated groups (total treated), and comparing them to the control group there was also a significantly increased PR in the treated animals ( $58 \%$ vs. $31 \%, \mathrm{P}<0.05$, total treated and control, respectively). There was also a significantly increased $\mathrm{CR}$ in the hCG-treated group of experimental animals (57\% vs. $31 \%, \mathrm{P}<0.05, \mathrm{hCG}$ and $\mathrm{C}$ group, respectively), as well as in the total treated animals compared to the control group (51\% vs. $31 \%, \mathrm{P}<$ 0.05 , total treated and $\mathrm{C}$ group, respectively).

Comparing the results of PR and CR in our experiment, it is evident that the highest level of pregnancy loss after days 28-35 occurred in the GnRH/hCG group $(3 / 16,18.75 \%)$, while the lowest level of pregnancy loss was observed in the GnRH group $(1 / 14,7.14 \%)$, while pregnancy loss was intemediate in the hCG group $(2 / 19,10.52 \%)$. 

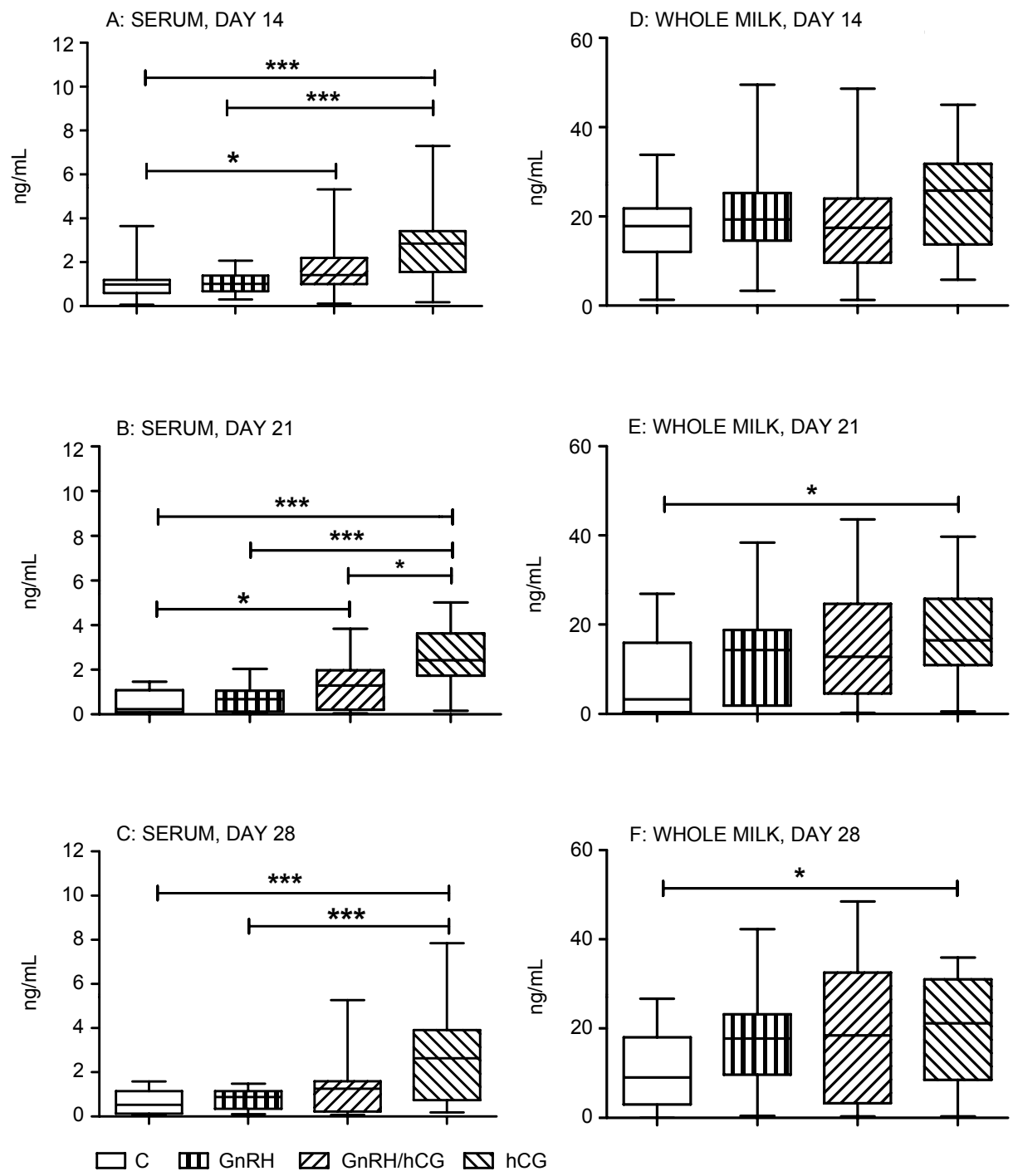

Fig. 1. Blood serum and milk $\mathrm{P} 4$ concentrations (median \pm interquartile range, $\mathrm{ng} / \mathrm{mL}$ ) in dairy cows of all experimental groups at days 14, 21 and 28 after AI and statistical significance of differences between median values; A, B, C-blood serum; D, E and F - whole milk; ${ }^{*} \mathrm{P}<0.05,{ }^{* * *} \mathrm{P}<0.001$

\section{Discussion}

The hypothesis that $\mathrm{P} 4$ secretion from the luteal tissue in high-producing dairy cows could be insufficient to support successful early pregnancy is not a new one, and it has been explored in several recent studies (Rizos et al., 2012; 
Binversie et al., 2012; Nascimento et al., 2013). However, there is a general lack of information regarding blood serum and milk P4 concentrations during the oestrus cycle in Simmental dairy cows, and its role in early pregnancy, especially after oestrus synchronisation. Furthermore, there is a renewed interest in the usage of hCG in oestrus synchronisation protocols in dairy cows, with the incorporation of hCG in the modified double-Ovsynch protocol (Binversie et al., 2012).

\section{Table 4}

The effect of different treatment protocols on pregnancy rate (PR) and calving rate (CR) in the experimental animals

\begin{tabular}{lll}
\hline Group & PR (\%) & CR (\%) \\
\hline C & $31^{\mathrm{b}}(8 / 26)$ & $31^{\mathrm{b}}(8 / 26)$ \\
GnRH & $54^{\mathrm{a}}(14 / 26)$ & $50^{\mathrm{a}, \mathrm{b}}(13 / 26)$ \\
GnRH/hCG & $62^{\mathrm{a}}(16 / 28)$ & $46^{\mathrm{a}, \mathrm{b}}(13 / 28)$ \\
hCG & $63^{\mathrm{a}}(19 / 30)$ & $57^{\mathrm{a}, \mathrm{c}}(17 / 30)$ \\
\hline Total treated & $58^{\mathrm{a}}(49 / 84)$ & $51^{\mathrm{a}}(43 / 84)$ \\
\hline
\end{tabular}

PR: pregnancy rate at days 28-35; CR: Calving rate (percentage of calved animals); $\mathrm{C}$ : control group. ${ }^{\mathrm{a}, \mathrm{b}, \mathrm{c}} \mathrm{Z}$ test of statistical significance of differences in the PR and $\mathrm{CR}$ between control and treatment groups ( $\mathrm{GnRH}, \mathrm{GnRH} / \mathrm{hCG}$ and $\mathrm{hCG}$ ) including the total number of treated animals vs. control; numbers with different superscripts are significantly different $(\mathrm{P}<0.05)$ (http://www. socscistatistics.com/tests/ztest/)

After a meta-analysis of 17 studies Mann and Lamming (1999) have concluded that P4 supplementation during the first week of pregnancy results in an increase of pregnancy rate (PR), while treatment during the second and third weeks of pregnancy has no effect on PR. Progesterone concentration at day 5 after oestrus is positively correlated with embryonic development (Green et al., 2005). These findings suggest that $P 4$ supplementation between days 5-9 after AI has a more positive effect on maternal recognition of pregnancy than P4 treatments in the latter period (Mann et al., 2006). Several methods are available for P4 supplementation during early pregnancy in dairy cows, and treatment with hCG is one that has received notable attention (recently reviewed by Szenci, 2015). An increase of endogenous $\mathrm{P} 4$ concentrations after hCG treatment was reported by several authors (Schmitt et al., 1996a; Santos et al., 2001; Stevenson et al., 2007; Stevenson and Pulley, 2012). There are also several reports about the positive effect of hCG treatment on conception rate (Breuel et al., 1989; Rajamahendran and Sianangama, 1992). However, Stevenson et al. (2007) found no positive effect of hCG treatment on pregnancy outcome at the first service after calving, and several previous reports also confirmed this conclusion (Walton et al., 1990; Hanlon et al., 2005). Our previous work indicated that treatment with 
hCG in repeat-breeding dairy cows during the mid-luteal phase could increase plasma P4 concentration and improve reproduction efficiency (Gvozdić et al., 2013). This discrepancy in the reports about the effects of hCG treatment the reproduction efficiency led us to revisit this problem, especially having a situation that the Simmental breed is the most common on small dairy farms in the rural parts of Serbia. Furthermore, many field or farm veterinarians utilise a simple oestrus synchronisation protocol based on a single $\mathrm{PGF}_{2 \alpha}$ injection in animals with a palpable CL (with the records of no previous inseminations), expecting oestrus followed by successful pregnancy after AI.

The blood serum P4 concentrations found by us are lower than the level found in Holstein animals stimulated with hCG (Stevenson et al., 2012) but are comparable to concentrations detected in Holstein-Friesian dairy cows subjected to Ovsynch treatment (Vuković et al., 2016). Stevenson and Pulley (2012) reported that treatment with hCG (1000 IU) seven days after AI induces new luteal structures in about $70 \%$ of the treated animals and increases blood P4 level. Our results also indicate increased luteal tissue activity in hCG-treated animals (Fig. $1 \mathrm{~A}, \mathrm{~B}$ and $\mathrm{C}$ ), but the level of $\mathrm{P} 4$ was lower compared to that found in hCGtreated animals by Stevenson et al. (2012), in spite of the fact that we used $1500 \mathrm{IU}$ of hCG. This difference may have resulted from differences in the methodology of P4 determination (differences in the RIA test and procedure) or from the difference in innate P4 production and blood serum level in Simmental dairy cows. Furthermore, in hCG-treated Holstein cows Walton et al. (1990) reported P4 levels more similar to those found by us. However, besides possible differences in the methodology of blood serum or plasma P4 determination, we were able to demonstrate a significantly higher blood serum P4 concentration in the hCG-treated experimental groups of animals after AI.

The increased PR found in hCG-treated Simmental dairy cows after oestrus synchronisation and AI in our work indicates that some of the pregnancy failures are attributable to insufficient $\mathrm{P} 4$ production during the early stages of embryonic development. King et al. (2013) have found that higher plasma P4 concentrations in nulliparous dairy heifers as early as 4-6 days after insemination have a positive effect on first-insemination PR. There was a significant difference in pregnancy rate between heifers with plasma P4 between $0-2 \mathrm{ng} / \mathrm{mL}$ $(\mathrm{PR}=43 \%)$ and heifers with a $\mathrm{P} 4$ level $\geq 2 \mathrm{ng} / \mathrm{mL}(\mathrm{PR}=56-73 \%)$. However, heifers treated with hCG with a plasma P4 level $>2 \mathrm{ng} / \mathrm{mL}$ had significantly lower PR compared to the control animals (51\% vs. 64\%; King et al., 2013). Obviously, there are other factors that could have influenced PR under the experimental conditions reported by King et al. (2013), including age, semen type, and presence of a functional CL. In our experimental protocol we tried to decrease the possible effects of inaccurate oestrus detection, nonexistence of a functional $\mathrm{CL}$ and mistiming of AI, and we were able to demonstrate the positive effect of hCG treatment at day 7 after AI on PR in Simmental dairy cows. Unfortunately, 
we were not in the position to utilise ultrasound for the examination of all ovarian structures (CLs, follicles) during the whole duration of our experiment, but further studies should consider this.

There is an estimation suggesting that only around $50 \%$ of dairy cows in the United Kingdom calve to a particular insemination, indicating that pregnancy fails in about $50 \%$ of cows (Mann and Lamming, 1999). The timing and extent of pregnancy failure reviewed by Sreenan and Diskin (1986) indicated that fertilisation rate is around $90 \%$, and PR falls to around $80 \%$ by days $10-13$ due to failed embryonic development. The PR further falls to $60-65 \%$ by day 19 because of the inability of the developing embryo to prevent luteolysis and maintain sufficient progesterone secretion. By day 25 after breeding the pregnancy rate falls to a value between $25 \%$ and $30 \%$ due to embryonic mortality. Our data indicate that PR at days $28-35$ in all treated animals is significantly higher compared to the control animals ( $31 \%$ vs. $58 \%, \mathrm{P}<0.05$ for control and total treated, respectively), and hCG treatment was a significant factor contributing to that difference $(31 \%$ vs. $62 \%$ and $63, \mathrm{P}<0.05$, for control vs. $\mathrm{GnRH} / \mathrm{hCG}$ and $\mathrm{hCG}$, respectively). After the analysis of calving records and the calculation of CR there was still evidence that all our treatments had significantly improved reproductive efficiency (CR $31 \%$ vs. $51 \%, \mathrm{P}<0.05$, in the control and the total number of treated animals, respectively).

After comparing the results of PR and CR, we calculated the highest level of pregnancy loss in the GnRH/hCG group $(3 / 16,18.75 \%)$, the lowest level in the GnRH group and an intermediate level in the hCG group $(1 / 14,7.14 \%$ and $2 / 19,10.52 \%$, GnRH and hCG group, respectively). The interval between pregnancy diagnosis by means of ultrasonography in our work (days 28-35) and calving was very long, and there were many factors that could influence the experimental animals (Romano, 2004; Romano et al., 2006). During the first trimester spontaneous pregnancy loss in dairy cows could reach a percentage as high as 10-20\% (Romano, 2004; Santos et al., 2004). In the experiment conducted on 138 Holstein-Friesian dairy cows that were repeatedly examined by ultrasonography between days 26-58 after AI, Szenci et al. (1998) reported a total calving rate of $37.6 \%(52 / 138)$, and late embryonic mortality occurring in $8.6 \%$ of cows. However, the high pregnancy loss during our experiment could also originate from a false pregnancy diagnosis, since our criteria for a positive pregnancy did not comprise the detection of fetal heartbeats, and were based on the recognition of irregular-shaped, non-echogenic black spot or spots within the uterine lumen, representing the allantoic fluid, and a $\mathrm{CL}$ on the ipsilateral ovary. The accuracy of early pregnancy diagnosis in the bovine species could also be affected by position of the uterus relative to the pelvic inlet, with the uterus located far cranially being more prone to incorrect non-pregnancy diagnosis (Szenci et al., 1995). According to a recent study in herds with a high incidence of early fetal mortality of non-infectious nature at pregnancy diagnosis (days 28-34), 
treatment at the time of pregnancy diagnosis with progesterone in cows with one corpus luteum and with GnRH in cows with two or more corpora lutea should offer considerable benefits (Bech-Sàbat et al., 2009). Unfortunately, during our experiment the possible number of CL on the ipsilateral ovary (it either had or did not have CL) was not determined, which should be considered in our further studies of similar design.

Our results indicate that hCG treatment during the early luteal phase after a simple oestrus synchronisation protocol between 40 and 80 days after parturition could increase blood serum P4 concentration and PR at days 28-35 post-AI in Simmental dairy cows. There is also evidence that all our treatments increased CR in Simmental dairy cows.

\section{Acknowledgement}

This study was supported by the Ministry of Education, Science and Technology, Republic of Serbia, Project Grants No. 31050, No. III46009 and No. III46002.

\section{References}

Binversie, J. A., Pfeiffer, K. E. and Larson, J. E. (2012): Modifying the double-Ovsynch protocol to include human chorionic gonadotropin to synchronize ovulation in dairy cattle. Theriogenology 78, 2095-2104.

Bech-Sàbat, G., López-Gatius, F., García-Ispierto, I., Santolaria, J. P. and Serrano, B. (2009): Pregnancy patterns during the early fetal period in high producing dairy cows treated with GnRH or progesterone. Theriogenology 71, 920-929.

Breuel, K. F., Spitzer, J. C. and Henricks, D. M. (1989): Systemic progesterone concentration following human chorionic gonadotropin administration at various times during the estrous cycle in beef heifers. J. Anim. Sci. 76, 1564-1572.

De Rensis, F., López-Gatius, F., Garcia-Ispierto, I. and Techakumpu, M. (2010): Clinical use of human chorionic gonadotropin in dairy cows: An update. Theriogenology 73, 1001-1008.

Green, M. P., Hunter, M. G. and Mann, G. E. (2005): Relationships between maternal hormone secretion and embryo development on Day 5 of pregnancy in dairy cows. Anim. Reprod. Sci. 88, 179-189.

Gvozdić, D., Barna, T., Milovanović, A., Stančić, B., Božić, A., Jovanović, B. I., Milanović, S., Vuković, D. and Šuluburić, A. (2013): Human chorionic gonadotrophin (hCG) in the repeat-breeding dairy cows reproduction. In: Congress Proceedings, XIII Middle European Buiatrics Congress, Belgrade, Serbia, pp. 192-202.

Gvozdić, D., Stančić, I., Savović, M., Stančić, B., Božić, A., Jovanović, B. I. and Barna, T. (2011): Reproductive efficiency in high-milking dairy cows after calving. Contemp. Agric. 60, 86-97.

Hanlon, D. W., Jarratt, G. M., Davidson, P. J., Millar, A. J. and Douglas, V. L. (2005): The effect of hCG administration five days after insemination on the first service conception rate of anestrous dairy cows. Theriogenology 63, 1938-1945.

Khoramian, B., Farzaneh, N., Talebkhan, A., Garoussi, M. and Mohri, M. (2011): Comparison of the effects of gonadotropin-releasing hormone, human chorionic gonadotropin or progesterone on pregnancy per artificial insemination in repeat-breeder dairy cows. Res. Vet. Sci. 90, 312-315. 
King, S. G., Dobson, H., Royal, M. D., Christley, R. M., Murray, R. D., Routly, J. E., Smith, R. F. and Mann, G. E. (2013): Identification of inadequate maternal progesterone concentrations in nulliparous dairy heifers and treatment with human chorionic gonadotrophin. Vet. Rec. 173, 450.

Macmillan, K. L. (2010): Recent advances in the synchronization of estrus and ovulation in dairy cows. J. Reprod. Dev. 56, S42-S47.

Maillo, V., Duffy, P., O’Hara, L., de Frutos, C., Kelly, A. K., Lonergan, P. and Rizos, D. (2014): Effect of hCG administration during corpus luteum establishment on subsequent corpus luteum development and circulating progesterone concentrations in beef heifers. Reprod. Fertil. Dev. 26, 367-374.

Mann, G. E. and Lamming, G. E. (1999): The influence of progesterone during early pregnancy in cattle. Reprod. Dom. Anim. 34, 269-274.

Mann, G. E. and Lamming, G. E. (2001): Relationship between maternal endocrine environment, early embryo development and the inhibition of the luteolytic mechanism in the cows. Reproduction 121, 175-180.

Mann, G. E., Fray, M. D. and Lamming, G. E. (2006): Effects of time of progesterone supplementation on embryo development and interferon- $\tau$ (tau) production in the cow. Vet. J. 171, 500-503.

Nascimento, A. B., Souza, A. H., Guenther, J. N., Costa, F. P., Sartori, R. and Wiltbank, M. C. (2013): Effects of treatment with human chorionic gonadotrophin or intravaginal progesterone-releasing device after AI on circulating progesterone concentrations in lactating dairy cows. Reprod. Fertil. Dev. 25, 818-824.

Pursley, J. R., Mee, M. O. and Wiltbank, M. C. (1995): Synchronization of ovulation in dairy cows using PGF2a and GnRH. Theriogenology 44, 915-923.

Rajamahendran, R. and Sianangama, P. C. (1992): Effect of human chorionic gonadotropin on dominant follicles in cows: formation of accessory corpora lutea, progesterone production and pregnancy rates. J. Reprod. Fertil. 95, 577-584.

Rizos, D., Scully, S., Kelly, A. K., Ealy, A. D., Moros, R., Duffy, P., Al Naib, A., Forde, N. and Lonergan, P. (2012): Effects of human chorionic gonadotrophin administration on day 5 after oestrus on corpus luteum characteristics, circulating progesterone and conceptus elongation in cattle. Reprod. Fertil. Dev. 24, 472-481.

Romano, J. E. (2004): Early pregnancy diagnosis and embryo/fetal mortality in cattle. PhD Thesis. Physiology of Reproduction, College of Agricultural and Life Sciences, Texas A\&M University.

Romano, J. E., Thompson, A. J., Forrest, W. D., Westhusin, E. M., Tomaszweski, A. M. and Kraemer, C. D. (2006): Early pregnancy diagnosis by transrectal ultrasonography in dairy cattle. Theriogenology 66, 1034-1041.

Royal, M. D., Darwash, A. O., Flint, A. P. F., Webb, R., Woolliams, J. A. and Lamming, G. E. (2000): Declining fertility in dairy cattle: changes in traditional and endocrine parameters of fertility. Anim. Sci. 70, 487-502.

Santos, J. E., Thatcher, W. W., Chebel, R. C., Cerri, R. L. and Galvao, K. N. (2004): The effect of embryonic death rates in cattle on the efficacy of estrus synchronization programs. Anim. Reprod. Sci. 82-83, 513-535.

Santos, J. E. P., Thatcher, W. W., Pool, L. and Overton, M. W. (2001): Effect of human chorionic gonadotropin on luteal function and reproductive performance of high-producing lactating Holstein dairy cows. J. Anim. Sci. 79, 2881-2894.

Schmitt, E. J., Barros, C. M., Fields, P. A., Fields, M. J., Diaz, T., Kluge, J. M. and Thatcher, W. W. (1996a): A cellular and endocrine characterization of the original and induced corpus luteum after administration of a gonadotropin-releasing hormone agonist or human chorionic gonadotropin on day five of the estrous cycle. J. Anim. Sci. 74, 1915-1929.

Schmitt, E. J., Diaz, T., Barros, C. M., De La Sota, R. L., Drost, M., Fredriksson, E. W., Staples, C. R., Thorner, R. and Thatcher, W. W. (1996b): Differential response of the luteal phase and 
fertility in cattle following ovulation of the first-wave follicle with human chorionic gonadotropin or an agonist of gonadotropin-releasing hormone. J. Anim. Sci. 74, 1074-1083.

Shelton, K., Gayerie De Abreu, M. F., Hunter, M. G., Parkinson, T. J. and Lamming, G. E. (1990): Luteal inadequacy during the early luteal phase of subfertile cows. J. Reprod. Fertil. 90, 1-10.

Sianangama, P. C. and Rajamahendran, R. (1992): Effect of human chorionic gonadotropin administrated at specific times following breeding on milk progesterone and pregnancy in cows. Theriogenology 38, 85-96.

Sreenan, J. M. and Diskin, M. G. (1986): The extent and timing of embryonic mortality in the cow. In: Sreenan, J. M. and Diskin, M. G. (eds) Embryo Mortality in Farm Animals. Martinus Nijhoff, Dordrecht. pp. 1-11.

Stevenson, J. S. and Pulley, S. L. (2012): Characteristics and retention of luteal structures, extended postinsemination cycle, progesterone, and pregnancy-specific protein B in serum after human chorionic gonadotropin treatment of dairy cows. J. Dairy Sci. 95, 4396-4409.

Stevenson, J. S., Tenhouse, D. E., Portaluppi, M. A., Eborn, D. R., Kacuba, S. and Dejarnette, J. M. (2007): Interventions after artificial insemination: Conception rates, pregnancy survival, and ovarian responses to gonadotropin-releasing hormone, human chorionic gonadotropin, and progesterone. J. Dairy Sci. 90, 331-340.

Szenci, O. (2015): Recent possibilities for the diagnosis and pharmacological control of pregnancy loss in dairy cow. J. Life Sci. (Libertyville) 9, 171-180.

Szenci, O., Beckers, J. F., Humblot, P., Sulon, J., Sasser, G., Taverne, M. A. M., Varga, J., Baltusen, R. and Schekk, Gy. (1998): Comparison of ultrasonography, bovine pregnancy specific protein $\mathrm{B}$, and bovine pregnancy associated glycoprotein 1 test for pregnancy detection in dairy cows. Theriogenology $\mathbf{5 0 , 7 7 - 8 8 . ~}$

Szenci, O., Gyulay, Gy., Nagy, P., Kovács, L., Varga, J. and Taverne, M. A. M. (1995): Effect of uterine location relative to the pelvic inlet on the accuracy of early bovine pregnancy diagnosis by means of ultrasonography. Vet. Q. 17, 37-39.

Vuković, D., Božić, A., Relić, R., Stančić, B., Gvozdić, D. and Kučević, D. (2016): Progesterone concentration in milk and blood serum and reproductive efficiency of cows after Ovsynch treatment. Turkish J. Vet. Anim. Sci. 40, 75-80.

Walton, J. S., Halbert, G. W., Robinson, N. A. and Leslie, K. E. (1990): Effects of progesterone and human chorionic gonadotropin administration five days postinsemination on plasma and milk concentrations of progesterone and pregnancy rates of normal and repeat breeder dairy cows. Can. J. Vet. Res. 54, 305-308. 